\title{
Mimarlık eğitiminde maket: örnek bir yapı bilgisi dersi uygulaması
}

Alper Bodur, Naide Sevim Koşan, Yeşim Görmüş

Önerilen atıf: Bodur, A., Sevim Koşan, N., \& Görmüş, Y. (2020). Mimarlık eğitiminde maket: örnek bir yapı bilgisi dersi uygulaması, Uluslararası Sosyal Bilimler Eğitimi Dergisi, 6(2), 128-145. DOI:

$10.47615 /$ issej. 748821

Makale linki: https://doi.org/10.47615/issej.748821 ○ 2020 Yazar(lar). Baskınlar ve izinler:
USBED/Uluslararası Sosyal Bilimler Eğitimi
Dergisi

USBED/Uluşlararası Sosyal Bilimler Eğitimi Dergisi hakemli bir çevrimiçi dergidir. Bu makale araştırma, ögretim ve özel çalışmalar amacıyla kullanılabilit. Makalenin içerı́ginden yanlızca yazarlar sorumludur Dergi makảlelerin telif hakkına sahiptir. Yayıncı, araşstırma materyalinin kullanımıyla baglantılı veya dogrudan veya dolaylı
talep veya masraf veya zarardan sorumlu tutulamaz. 


\title{
Mimarlık eğitiminde maket: örnek bir yapı bilgisi dersi uygulaması
}

\author{
Alper Bodur (1) Naide Sevim Koşan [1] Yeşim Görmüş (1) \\ Mimarlık Fakültesi, Ondokuz Mayıs Üniversitesi, Samsun, 55139, Türkiye
}

ÖZ

Mimarlık öğrencileri, proje derslerinde tasarladıkları yapıların uygulanabilirliği konusunda bir takım bilgi eksiklikleri yaşamaktadırlar. Bu eksikliklerin giderilmesi için, eğitim süresince yapı ile ilgili destek dersleri verilmektedir. Bu derslerde, verilen bilgilerin pekiştirilmesi doğrultusunda, maket yapımı; yapı bilgisi derslerinde öğrenmenin önemli bir tamamlayıcısı haline gelmektedir. Bu araştırmada, mimarlık öğrencilerinin üç boyutlu görsel algılarını artıracak ve edinim biçimlerini geliştirecek maket yapımı yönteminin etkililiği ölçülmeye çalışılmaktadır. Arastırmanın kapsamını; Ondokuz Mayıs Universitesi, Mimarlık Fakültesi, Mimarlık Bölümü, 20192020 Eğitim Öğretim Yılı Güz Dönemi'nde verilen "Yapı Bilgisi I" dersi kapsamında yapılan maket çalışmaları ve bu dersi alan öğrenciler ile yapılan anket uygulaması oluşturmaktadır. Maket çalışması ile öğrencilerin ileriye yönelik hem tasarım, hem de uygulama aşamasında kullanabilecekleri bilgilerle donatımaları hedeflenmiştir. Bununla birlikte, arastırmanın öğrencilere sağladığı katkılar ve bazı eksikliklerin belirlenebilmesi amacıyla dönem sonunda bir anket çalışması gerçekleştirilmiştir. Öğrencilerin, calısma kapsamında hazırlanan anket sorularına verdiği cevaplarda, maket çalışması ile derste işlenen konuların daha iyi kavrandığı, yapı malzemeleri konusunda bilgi düzeylerinin arttığı, çalışmanın proje derslerinde de yararlı olduğu sonuçları ortaya çıkmıştır. Bu doğrultuda, mimarlık eğitiminde proje atölyelerine destek olarak işlenen yapı bilgisi derslerinde maket uygulamalarının gerçekleştirilmesinin öğrencilere mesleki açıdan büyük bir katkı ve avantaj sağlayacağı ortaya koyulmaktadır. Çalışma sonucunda gerek bölüm müfredat içeriği, gerekse ders içeriği ve uygulaması üzerine bazı özlü önerilerde bulunulmaktadır.
MAKALE TARİHI

Geliș tarihi 06 Haziran 2020

Kabul tarihi 12 Kasım 2020

Yayım tarihi 31 Aralık 2020

ANAHTAR KELIMER

Mimarlık eğitimi, yapı bilgisi, maket uygulaması

Makale Türü

Arastırma makalesi 


\title{
Model in architectural education: a sample building construction lesson practice
}

\author{
Alper Bodur, Naide Sevim Koşan, Yeşim Görmüş \\ Department of Architecture, Ondokuz Mayıs University, Samsun, 55139, Turkey
}

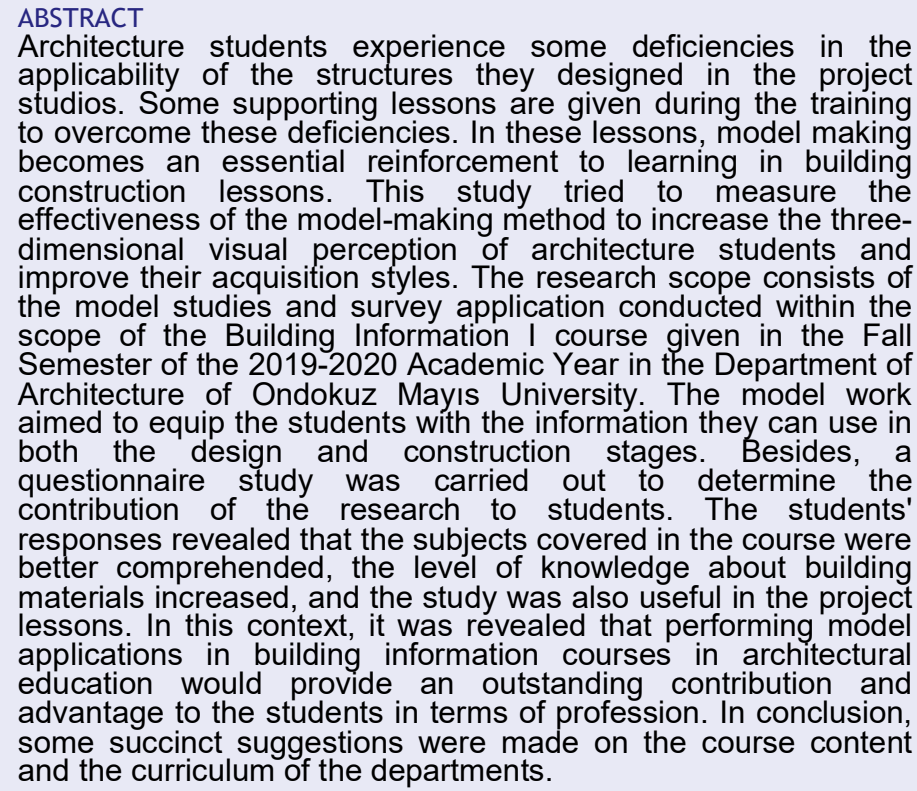
materials increased, and the study was also useful in the project lessons. In this context, it was revealed that performing model applications in building information courses in architectural education would provide an outstanding contribution and advantage to the students in terms of profession. In conclusion, some succinct suggestions were made on the course content and the curriculum of the departments.

ARTICLE HISTORY

Received 06 June 2020

Accepted 12 November 2020

KEYWORDS

Architectural education, building construction, model practice

Type of the Paper Research article

\section{Introduction}

Architecture is one of the disciplines built on probabilities (Malecha, 2008) and also a profession related to different fields such as technology, culture, and history (Kizilyaprak, 2019). The relationship between humans and the environment forms the basis of architectural research (Belir, 2019). It is possible to characterize architecture as a process of producing functional and artistic products in line with the ordinary judgments put forward, taking into account the public interest (Şensoy and Yamaçl1, 2015).

Architecture is dynamic and open to the innovation profession, and it changes in specific periods (Lökçe, 2002). In traditional education, by giving information to the student, the understanding that gives importance only to the mental development has been replaced by the knowledge that can take the society forward and question the conditions (Illerisoy and Ayc1, 2019). In this sense, architectural education can be divided into three as below:

1. The period when there were no architectural schools.

2. The period when architectural schools emerged.

3 . The period when the project studios became institutionalized with architectural education (Özkaynak and Acar Ata, 2018). 
The desire to realize and apply different designs has integrated the field of architecture with computers. Thus, a new rapid change process has been introduced in architectural practices and education (Mihlayanlar and Tachir, 2019). Today, various methods are used in architectural design education due to the development of technology and the rapid advancement of science. However, even though the design methods and the applied methods are different, the teaching methods do not change basically (Özkaynak and Acar Ata, 2018). One of the most critical objectives of architectural education is to enable architect candidates to meet the problems they will encounter in their professional lives during the learning phase and offer solutions. Students' access to information, right or wrong concrete examples, will positively impact their professional development (Belir, 2019). Architectural education aims to teach the candidate the creative thinking methodology, and therefore to train architects who can produce creative ideas (Tantekin Çelik, Bağrıaçı, and Laptalı Oral, 2012). In recent years, depending on the developments occurring, especially in the building sector and education sector, it is observed that different searches have come to the agenda in addition to the approaches that are widely used in teaching information about design and construction in architectural education (Erbil, 2008). With these developments, the use of information acquired or required by architects in systems and structures plays a vital role in architecture development. The knowledge and skills of architects using these opportunities can reach a much higher level.

One of the universities' essential duties is to ensure that individuals, the most valuable asset of society, are raised in a qualified way. The universities should organize their educational activities by considering this (Illhan and Kalayc1, 2018) how the faculty members plan the lesson to raise students in line with the social profile required by the age and which methods and techniques they use for the skills expected to be developed in students is a fundamental question (Karakaş Özür, 2019). The economic, social, ideological, and political factors that form some architectural profession practice inputs affect the architect himself, his sense of identity, his relationship with his profession, and the way he perceives and evaluates his career (Onur, 2019).

Especially in developing countries such as Turkey, universities have to contribute to the sector by producing information and bringing practical solutions to problems and education and training activities (Aktas, 2019). Accordingly, architectural education includes application besides theoretical knowledge, and intertwined with professional practice is essential in maturing the students who are preparing for the profession (Illerisoy and Ayc1, 2019). The teaching of crucial information such as building, construction systems, building components, and building elements in architectural education contributes to increasing building design skills in the education process. In this context, the building construction lessons' information gains importance in the architectural learning process. This information should cover activities related to practice rather than just an abstract lecture method. It is thought that the lecturers' professional experience, interests, and adequacy in explaining the course will be beneficial but insufficient in understanding the subject.

For this reason, it is necessary to reinforce the knowledge of building elements taught with theoretical and practical in introductory courses related to building with natural materials and scale models. The model enables the design to be shaped with a more compelling, more meticulous experience and attitude than other two-dimensional media techniques and transferred to the target audience (Gergin, 2015). Accordingly, it is inevitable to make model studies to better learn the structural elements whose theoretical knowledge is given and their drawings. For this reason, it is necessary to conduct field trips on the application or model studies of the subjects (foundation, wall, floor, chimney, 
etc.) covered in the course with natural materials. Within this study's scope, the students made $1 / 10$ scale model work $(30 * 30 \mathrm{~cm})$ with the materials used in building construction to better understand the subject, improve material behavior, and improve practice in their professional architectural life. As a result, the model's contributions to the students at the end of the lesson and suggestions for future studies are brought.

\section{Related Courses for Construction in Architectural Education in Turkey}

In the design workshops that form the primary axis of architectural education, the selection of suitable building materials in many components from the structure to the building's outer shell during the development of different building programs is supported by many related courses in parallel (Yücel, 2018). The architectural design studio is located in the center of the architecture department of education programs in Turkey and is supported by another curriculum (Erbil, 2008). These courses are generally gathered under the Building Construction, History of Architecture, and Restoration Departments (Özyaba, Polat, Erbil, and Yurtkuran, 2013).

Indeed, students who cannot be directly involved with building materials during their undergraduate education will have problems, such as prolonging decision-making processes in architectural projects. When we look at building construction lesson applications, which is one of the introductory courses about building, it is seen that the subject is generally taught in the form of theoretical and drawing applications. The directions given about the structure aim to study the most natural construction systems and materials in general and teach the selection of this system and the spatial effect. Architectural project studios consist of three parts; (1) design knowledge and process, (2) architectural aesthetic values, (3) structure, construction, and material use (Tokman, 2012). Of these, the architecture, building, and material usage information are given in the structure's courses. The compulsory courses related to building construction in some universities providing architectural education by semesters in Turkey (10 states, ten private universities) are shown in Table 1. The elective courses are not included in the table since they are not compulsory for all students.

Table 1. Numbers of building construction related courses at some universities by semesters in Turkey

\begin{tabular}{lccccccccccc}
\hline & Type & 1th & 2nd & 3th & 4th & 5th & 6th & 7th & 8th & Total & ECTS \\
\hline Istanbul Technical University & State & 1 & 2 & 4 & 2 & 1 & 1 & 1 & - & 12 & 45,5 \\
Yildiz Technical University & State & - & 3 & 2 & 1 & 2 & 3 & 1 & - & 12 & 36 \\
Gazi University & State & 1 & 2 & 3 & 2 & 2 & 1 & 2 & - & 13 & 44 \\
The İzmir Institute of Technology & State & - & 2 & 3 & 2 & 3 & 2 & 1 & - & 13 & 50 \\
Dokuz Eylül University & State & 1 & 2 & 3 & 2 & 3 & 2 & - & - & 13 & 56 \\
Eskisehir Technical University & State & - & 2 & 3 & 2 & 2 & 1 & 1 & 1 & 12 & 45,5 \\
Gebze Technical University & State & - & 2 & 3 & 2 & 2 & 1 & 1 & 1 & 12 & 42 \\
Mimar Sinan Fine Art University & State & 3 & 3 & 3 & 1 & 1 & - & - & 1 & 12 & 38 \\
Karadeniz Technical University & State & 1 & 2 & 2 & 2 & 1 & - & 1 & - & 9 & 34 \\
Ondokuz Mayis University & State & - & 1 & 2 & 1 & 1 & - & - & 1 & 6 & 22 \\
Bilkent University & Private & - & - & 1 & 2 & 2 & 1 & - & - & 6 & 26,5 \\
MEF University & Private & - & 1 & 1 & 1 & 1 & - & - & - & 4 & 19 \\
Özyeğin University & Private & - & - & 2 & 2 & - & 1 & 1 & 1 & 7 & 29 \\
TED University & Private & - & - & 1 & - & - & 1 & - & - & 2 & 10 \\
İstanbul Bilgi University & Private & - & - & 2 & 2 & - & - & - & 1 & 5 & 29 \\
Bahçeşehir University & Private & - & 1 & 2 & 2 & 1 & - & - & - & 6 & 24 \\
Fatih Sultan Mehmet University & Private & - & 1 & 2 & 2 & 1 & - & 1 & 1 & 8 & 34 \\
İzmir University of Economics & Private & - & - & 2 & 2 & 1 & 1 & 1 & - & 7 & 28 \\
Yeditepe University & Private & - & 1 & 1 & 1 & 1 & 1 & - & - & 5 & 26 \\
Kadir Has University & Private & - & - & 2 & 2 & 1 & 1 & - & - & 6 & 24 \\
\hline
\end{tabular}


It is seen in Table 1 that the teaching at each university is different. However, the number of courses and ECTS credits of them is higher in-state universities. In some public universities such as ITU, KTU, Gazi, Dokuz Eylul, and Mimar Sinan, building construction-related courses start from the first semester. Although these courses start in the second semester in some of the foundation universities, it is understood that the classes generally begin from the third semester. It is observed that in public universities, the courses are mostly in the 3rd semester and foundation universities in the 3rd, 4th, and fifth semesters. Accordingly, it can be said that students studying in public universities receive more courses about building construction from students studying in foundation universities and have more knowledge about the building.

In this context, it is seen that the lessons related to the structure given in Ondokuz Mayis University, Faculty of Architecture, Department of Architecture, which is the subject of the research, are few compared to other state universities and almost equal to foundation universities. The low number of lessons is because the department started its education and training activities as of the 2013-2014 academic year. Over time, it is predicted that this number will match the increasing number of faculty members and curriculum updates as in the name of courses at public universities.

\section{Methodology}

The study was carried out in four stages. In the first two stages, there are preparation and infrastructure building processes for work. In the third stage, a model application was carried out in the course to provide architecture students with a better understanding of the course subjects, improve their three-dimensional visual perception, and increase their knowledge about building detailed solutions. In the last stage, a questionnaire was applied to learn the effect of the model application on learning and its contribution to the students, measure the effectiveness of the model teaching method, and make suggestions to improve the course content in the future. In Table 2, all stages of the study are shown respectively.

Table 2. Stages of the model work.

\begin{tabular}{|c|c|c|}
\hline Stage & Process & Content \\
\hline 1 & $\begin{array}{l}\text { Preparation } \\
\text { (Obtaining preliminary } \\
\text { information) }\end{array}$ & $\begin{array}{l}\text { 1.1. Introduction to the course } \\
\text { 1.2. Specifying the model request } \\
\text { 1.3. Explanation of the content of the model } \\
\text { 1.4. Model samples and application videos }\end{array}$ \\
\hline 2 & $\begin{array}{l}\text { Creating Infrastructure } \\
\text { (Knowledge) }\end{array}$ & $\begin{array}{l}\text { 2.2. Sample video and photo display } \\
\text { 2.3. Drawing at the end of the lesson } \\
\text { 2.4. Announcement of the desired list about model application } \\
\text { 2. Determination of model aroups }\end{array}$ \\
\hline 3 & $\begin{array}{l}\text { Models } \\
\text { (Final Product) }\end{array}$ & $\begin{array}{l}\text { 3.1. Analysis and synthesis phase of information } \\
\text { 3.2. Transfer of information to the model } \\
\text { 3.3. Learning team work }\end{array}$ \\
\hline 4 & $\begin{array}{l}\text { Observation and Evaluation of } \\
\text { Models }\end{array}$ & $\begin{array}{l}\text { 4.1. Finishing of models } \\
\text { 4.2. Evaluation of models } \\
\text { 4.3. Analysis of students' learning status with model } \\
\text { 4.4. Future evaluation of the results (survey) }\end{array}$ \\
\hline
\end{tabular}

\section{Preparation and infrastructure phase}

During the preparation phase of the study, general information about the lesson was given to the students. It was explained that they would make models in individuals or groups to understand the course subjects better. Then, the students watched sample photos and videos about the models' construction processes, so they were provided to get preliminary 
information about the study. Also, it was stated that to produce a qualified model product, it was necessary to start the models during the lesson gradually. The course was taught to explain the weekly subjects and have the drawing applications done on the same day after the lessons. Within the course's scope, general concepts related to building and structure, construction systems, building elements, foundations, load-bearing systems, walls, floors, insulations, and chimneys were explained. It was emphasized that all this content described in the lesson should be considered by referring. It was conveyed to the students that making the model gradually during the lesson had more advantages. While explaining the course subjects, some information students can gain experience was also given. For instance, students were given an idea about taking necessary precautions despite concrete cracking during concrete manufacture. In this way, it was tried to provide students to understand the behavior of building materials during the construction phase. Thus, both theoretical and practical knowledge of the students regarding building knowledge and application were strengthened.

\section{Model making phase}

Model studies consist of 89 students and 20 groups in total, with a minimum of 3 people and a maximum of 6 people, apart from a group of 1 . The desired study was notified to the students with all details and the list's announcement regarding the application.

Table 3. The stages of some models

Group 6 Stage 1 Stage 2 3


After the groups were determined, the students made a model study, covering all the subjects in the course. Model studies applied with 20 groups ( 89 students) in this direction were carried out with four stages as: (1) Foundation types preferred by the groups will be implemented, (2) Vertical structure elements (columns) will be made, (3) The flooring types preferred by the groups will be applied, (4) Floor and wall covering layers will be shown. Table 3 shows the stages of some models. The instructors evaluated the resulting products comparatively, considering how and how much of the course topics covered in the model were processed. The criticisms made during the evaluation were not conveyed to the students. Model studies have resulted in better than expected. The resulting products were exhibited in the Faculty Exhibition Area between February 17 and March 16,2020 , to let other students see the works and encourage the students who put the products forward. Also, the lecturers' names and all students who presented the final products were added to the exhibition poster.

\section{Survey Application}

At the beginning of the next semester, a survey was conducted with 53 students out of 89 who carried out the model studies. In the questionnaire, there were six elective and one comment questions. All of the questionnaire's elective questions were asked to be evaluated in five different criteria $(1=$ Definitely no, $2=$ No, 3: Partially, 4: Yes, 5: Definitely yes). The selected criteria in the survey are; (1) It would be beneficial to increase the weekly course hours of the course, (2) The number of courses related to the building should be increased, (3) I better understood the applications made during the semester with the model work, (4) I have increased my knowledge about building materials with the model work, (5) The instructor should evaluate the final work, (6) Model application within the scope of the course has started to be useful in architectural design lessons, (7) Self-criticism of the resulting product (model).

\section{Findings}

In this article, the teaching method's effectiveness was analyzed over the models made by students within the scope of the "Building Information I" course given in the Fall Semester of the Ondokuz Mayis University, Department of Architecture. In this way, it was evaluated how the students' basic knowledge about the building could be reinforced and improved. Afterward, a questionnaire was conducted with the students taking the course, and their evaluations were taken. With these evaluations, students' problems in model making and the didactic effect of model making in the lesson were examined. In this way, the gains and difficulties that the students obtained with the model study were questioned, and some suggestions about the course were developed by examining the survey results. 
Table 4. Results for the criterion "It would be beneficial to increase the weekly course hours of the course."

\begin{tabular}{lccl}
\hline & Number & $\%$ & \\
\hline Definitely no & 15 & 28,3 & \\
No & 17 & 32,1 & \\
Partially & 13 & 24,5 & \\
Yes & 5 & 9,4 & \\
Definitely yes & 3 & 5,7 & \\
Total & 53 & 100,0 & \\
\hline
\end{tabular}

In Table 4, there is an evaluation of the criterion "it would be beneficial to increase the weekly course hours of the lesson" in the survey. Most of the students taking the course answered "no" and "absolutely no". On the other hand, a low rate answered "yes" and "absolutely yes". Accordingly, the students think that the lesson time is sufficient, and it is not beneficial to increase it. As seen in Table 5, one-third of the students taking the course answered "partially" to the criterion "the number of courses related to the structure should be increased". On the other hand, a quarter of them answered "no" and "absolutely not". Students who answer "yes" and "absolutely yes" are close to half.

Table 5. Results for the criterion "The number of courses related to the building should be increased."

\begin{tabular}{lccl}
\hline & Number & $\%$ & \\
\hline Definitely no & 4 & 7,5 & \\
No & 10 & 18,9 & \\
Partially & 17 & 32,1 & \\
Yes & 15 & 28,3 & \\
Definitely yes & 7 & 13,2 & \\
Total & 53 & 100,0 & \\
\hline
\end{tabular}

When the results in Table 4 and Table 5 are evaluated together, it can be said that students want to obtain different experiences and knowledge with various building courses instead of increasing the current course time. Students who want the number of lessons to increase are in the majority. Also, a small number of students do not want the number of lessons to increase. It can be stated that the reason for this is the difficulty of building courses and the technical dimension of the information given in the course content. According to the students, weekly lesson hours are sufficient for the course, while the lessons containing other information about the structure are insufficient and should be increased. Table 6 shows the answers to the criterion "I understood better the applications made during the semester with the model work". Accordingly, most of the students taking the course answered "yes" and "absolutely yes", while a small percentage answered "no" and "absolutely no". To these results, most of the students think that model making helps to grasp the subjects in the learning process, and thus the subjects are better understood. It is seen that it is beneficial for students to make the model applications in the building lessons. 
Table 6. Results for the criterion "I better understood the applications made during the semester with the model work."

\begin{tabular}{lcc|l}
\hline & Number & $\%$ & \\
\hline Definitely no & 2 & 3,8 & \\
No & 6 & 11,3 & \\
Partially & 9 & 17,0 & \\
Yes & 21 & 39,6 & \\
Definitely yes & 15 & 28,3 & \\
Total & 53 & 100,0 & \\
\hline
\end{tabular}

As seen in Table 7, most of the students who took the course answered "yes" and "absolutely yes" to the criterion "I have increased my knowledge about building materials with the model work". On the other hand, a low rate replied "no" and "absolutely no", and a fifth of them preferred to answer "partially".

Table 7. Results for the criterion "I have increased my knowledge about building materials with the model work."

\begin{tabular}{lcc|l}
\hline & Number & $\%$ & \\
\hline Definitely no & 2 & 3,8 & \\
No & 3 & 5,7 & \\
Partially & 12 & 22,6 & \\
Yes & 25 & 47,2 & \\
Definitely yes & 11 & 20,8 & \\
Total & 53 & 100,0 & \\
\hline
\end{tabular}

According to these results, it can be stated that students' knowledge about building materials increased with the fact that they used real construction materials while making models. The presence of a small percentage of students who think their knowledge does not increase is due to the absence of a course on building materials in the department. As emphasized in Table 5, the students emphasize that there should be other lessons about structure, and they are conscious of this issue. In other words, it can be stated that students are conscious enough about the courses that will increase their knowledge level; they are aware of their deficiencies and make their choices in the right direction.

Table 8. Results for the criterion "The instructor should evaluate the final work."

\begin{tabular}{lccl}
\hline & Number & $\%$ & \\
\hline Definitely no & 4 & 7,5 & \\
No & 8 & 15,1 & \\
Partially & 14 & 26,4 & \\
Yes & 14 & 26,4 & \\
Definitely yes & 13 & 24,5 & \\
Total & 53 & 100,0 & \\
\hline
\end{tabular}

As seen in Table 8, about half of the students who took the course provided the answer "absolutely yes" and "yes" to the criterion "the instructor should evaluate the final work. 
About a quarter answered "partially," while a low percentage answered "no" and "absolutely no." According to these results, students believe that the lecturer's evaluation will contribute to the education process. The need to obtain information from the lecturer who teaches the course is seen in the modeling process students have done by themselves or in groups. For this reason, it is seen that students care about the continuous follow-up of the modeling process by the instructors, revising the stages, and generating ideas for the parts that need improvement. Table 9 includes evaluations regarding the criterion of "model application within the course's scope has started to be useful in the architectural design course". Nearly half of the students stated their preference as "partially" in their answer to the criterion, and one third answered "yes" and "absolutely yes." So, it can be stated that the students think that this study contributes to the architectural design lessons. Almost half of the students answered "partially" because the study was completed in a short time in terms of time, and the information and experiences obtained from the model work were not long enough to be transferred to the project processes. On the other hand, it is predictable that in the latter stages of studenthood, the ratio of "partially" answers will decrease and shift towards "yes" answers, and students' awareness will increase over time.

Table 9. Results for the criterion "Model application within the scope of the course has started to be useful in architectural design lessons."

\begin{tabular}{lccl}
\hline & Number & $\%$ & \\
\hline Definitely no & 3 & 5,7 & \\
No & 7 & 13,2 & \\
Partially & 25 & 47,2 & \\
Yes & 17 & 32,1 & \\
Definitely yes & 1 & 1,9 & \\
Total & 53 & 100,0 & \\
\hline
\end{tabular}

There are evaluations for the criterion "self-criticism of the final product (model)" in Table 10. Since this question is a comment question, the comments made are grouped according to the students.

Table 10. Results for the criterion "self-criticism of the resulting product (model)."

\begin{tabular}{lcc}
\hline & Number & $\%$ \\
\hline Model work was beneficial & 18 & 25,7 \\
Time planning error in model making & 14 & 20,0 \\
Negative effect of using cheap materials on the model & 10 & 14,3 \\
The resulting product is not of good quality & 9 & 12,9 \\
Real material usage difficulty & 4 & 5,7 \\
Model scale is small & 2 & 2,9 \\
Model scale is big & 2 & 2,9 \\
Model application is useful from drawing application & 2 & 2,9 \\
Group work was appropriate & 1 & 1,4 \\
Group work was not suitable & 1 & 1,4 \\
Scale of model was appropriate & 1 & 1,4
\end{tabular}


Accordingly, a significant proportion of the students stated that the model application was useful, that they made a planning error in the production of the model, and therefore they had difficulties, the use of cheap materials poorly reflected on the product, and their models were not sound. Therefore they did not find the final product of high quality. While some of the students are prone to group work, an equivalent part has had problems. Some of the students stated that they had difficulties in artistry due to the model's small scale, while others found the small scale controllable. However, a small proportion found the scale large. Some of the students stated that the model application was more useful than the course's drawing applications. Some of the students suggested that the model work be carried out during the course hours to spare time for other lessons. Only one student stated that a model work should not be included within the scope of the course. In summary, the survey results revealed the participant students' evaluations on the number, quality, and content of the courses related to the structure. In this way, suggestions were developed on the course process and possible changes.

\section{Discussion and Conclusion}

Architecture students have some knowledge deficiencies about the applicability of the structures they designed in the project courses. Support courses are given during the training to overcome these deficiencies. In these courses, model making becomes an essential complement to learning to reinforce the information provided. Accordingly, one of the classes' objectives is that students apply the construction phase as a model in the most realistic way and make them aware of the shortcomings in the application details and provide solutions.

In this study, student model works made within the scope of Building Construction I course given in Ondokuz Mayıs University (OMÜ), Faculty of Architecture, Department of Architecture, Fall Term of 2019-2020 Academic Year were examined, and their contributions to students are analyzed. As it can be understood from the applied models, it is possible to easily comprehend the structure information processed within the course scope with the model applications even at a $1 / 10$ scale. The answers given by the students to the questionnaire questions prepared within the scope of the study showed that the topics covered in the course were comprehended better, and the level of knowledge about building materials increased. It also revealed the results that the study was useful in project studios. In this regard, it is revealed that model applications will provide an advantage in professional life. As a result of the survey conducted in the study, it was revealed that the students wanted to have a different experience with other buildingrelated courses instead of increasing the course time.

\section{Implication and Suggestions}

Generally, the building-related courses are taught through reinforced concrete structures. The data revealed in the study, together with enhanced specific information, shows the necessity to open classes containing different material information such as wood and steel systems. This information will be experienced with the model studies to be made within the scope of these courses. Besides, the designs to be made in the project courses will be positively affected. Apart from building systems created with different materials, it is 
necessary to learn the walls, flooring, coating materials of buildings, etc. In addition to introductory building knowledge courses, courses containing material information must be included in the curriculum.

As some of the students stated, model applications are recommended to be applied within the course hours. Thus, it will be ensured that the information learned in the courses will be made in the form of learn-draw-model making, and therefore the process of making a model will proceed more efficiently during the semester. However, this requires increasing the weekly course hours. With this, the interpretation and evaluation of the students' presentations and results products can be provided with the discussion environment. Thus, more effective learning will be realized about building construction systems. In conclusion, this learning method is an effective and efficient way to allow students to learn more about the building structure and reinforce their existing knowledge on the issue.

\section{Research Limitations and Future Research}

This research is limited to the Building Construction I course given in the Fall Semester of the 2019-2020 Academic Year in the Department of Architecture of Ondokuz Mayis University. So it shows a semester result. Thus, the study's scope can be extended with other studies to be carried out at different universities. Thus, this study, which expresses a static situation, will enable evaluating the studies to be carried out on the subject in a dynamic training process. Accordingly, it will allow for comparison with other universities.

\section{Author Contributions}

"Introduction, A.B.; related courses for construction in architectural education in Turkey, A.B.; methodology, A.B., N.S.K., and Y.G.; findings, A.B., N.S.K., and Y.G.; discussion and conclusion, A.B., N.S.K.; implication and suggestions, A.B., N.S.K., and Y.G.; references, A.B., N.S.K.; writing, reviewing and editing, A.B.”

\section{Publication Ethics}

Research and Publication Ethics was complied.

\section{Acknowledgment}

The authors want to thank Asist. Prof. Dr. Serpil Kaptan, a graphic design expert, for her help in the exhibition poster design. 
ORCID

Alper Bodur (1) http://orcid.org/0000-0002-4048-1158

Naide Sevim Koşan (1) http://orcid.org/0000-0002-9157-8216

Yeşim Görmüş (1) http://orcid.org/0000-0002-5412-3132

\section{References}

Aktaş, G. G. (2019). İçmimarlık eğitiminde üniversite-sanayi işbirliği modeli: Yerinde, yaparak öğrenme. Sanat ve Tasarım Dergisi, 24, 35-49.

Belir, Ö. (2019). Mimarlık öğrencilerinin "Bütünleşik fiziksel aktivite merkezi” örneğinde mekân tasarımı deneyimleri. Modular, 2(1), 46-56.

Erbil, Y. (2008). Mimarlık eğitiminde yaparak/yaşayarak öğrenme. E-Journal of New World Sciences Academy, 3(3), 579-587.

Gergin, A. (2015). Sanat ve tasarım alanlarında maket yapımının tasarım, üretim ve sunum aşamalarına etkileri. Yedi, 14, 157-168. doi: 10.17484/yedi.08591

İlerisoy, Z. Y., \& Ayci, H. (2019). Mimarlık son sınıf öğrencilerinin alan seçimlerine yönelik bir değerlendirme. JRES, 6(2), 192-214.

İlhan, E., \& Kalaycı, N. (2018). Üniversitelerin lisans programlarında uygulanan çekirdek programların değerlendirilmesi. Yükseköğretim Dergisi, 8(3), 264-281. doi:10.2399/yod.18.014

Karakaş Özür, N. (2019). Yüksek öğretim coğrafya eğitiminde öğrenci merkezli ders uygulaması. Çankırı Karatekin Üniversitesi Karatekin Edebiyat Fakültesi Dergisi, 7(1), 1-24.

Kizilyaprak, N. (2019). An analysis of architectural technology education in Turkey. Mimarlık ve Yaşam Dergisi, 4(1), 39-53. doi: 10.26835/my.491641

Lökçe, S. (2002). Mimarlık eğitim programları: Mimari tasarım ve teknoloji ile bütünleşme. Gazi Üniversitesi Mühendislik Mimarlık Fakültesi Dergisi, 17(3), 1-16.

Malecha, M. J. (2008). Dönüşüm sürecinde mimarlık eğitimi: Üçüncü bir bilgi alanına doğru. Mimarlı, 340. 10 Şubat 2020 tarihinde <http://www.mimarlikdergisi.com/index.cfm?sayfa= mimarlik\&DergiSayi=290\&RecID=1707> adresinden erişildi.

Mıhlayanlar, E., \& Tachir G. (2019). Mimarlık eğitiminde bilgisayar destekli tasarımdan bina enformasyonuna. Artium, 7(2), 167-179.

Onur, B. (2019). Mimarın mesleki kimlik algısının boyutları. Insan ve Toplum Bilimleri Araştırmaları Dergisi, 8(1), 151-162.

Özkaynak, M., \& Acar Ata, İ. (2018). Mimari tasarım eğitiminde yaz okulu deneyimi: Öğrenci performansı üzerinden bir değerlendirme. İnönü Üniversitesi Sanat ve Tasarım Dergisi, 9(19), 77-92. doi: 10.16950/iujad.511970

Özyaba, M., Polat, S., Erbil, Y., \& Yurtkuran, S. (2013). Mimarlık öğrencilerinin sosyo-ekonomik durumlarının eğitim sürecindeki başarılarına etkisi. Uludağ Üniversitesi Mühendislik-Mimarlık Fakültesi Dergisi, 18(2), 1-6.

Şensoy, G., \& Yamaçlı, R. (2015). Disiplinlerarası bir içerik olarak mimarlık. Düzce Üniversitesi Bilim ve Teknoloji Dergisi, 3(2), 329-339.

Tantekin Çelik, G., Bağrıç̧ı, R., \& Laptalı Oral, E. (2012). Mimarlık bölümü öğrencilerinin akademik tükenmişlikleri. NWSA-Engineering Sciences, 7(1), 358-367.

Tokman, L. Y. (2012). Mimarlık Üzerine Bir Bilimsel Araştırma Tasarım Yöntem Uygulama. Ankara: Efil Yayınevi.

Yücel, G. (2018). Ahşap ve mimarlık eğitimi: İstanbul örneği. Mobilya ve Ahşap Malzeme Araştırmaları Dergisi, 1(2), 62-77. 


\section{Genișletilmiș Özet}

\section{Giriş}

Mimarlık eğitiminde güncel gelişmeler süregelmekte olup bu gelişmelerle birlikte mimarların edinmesi gereken bilgilerin tasarımlarda ve yapılarda kullanılması mimarlığın gelişmesinde önemli rol oynamakta, bu imkânları kullanan mimarların bilgi ve becerileri çok daha yüksek bir seviyeye gelebilmektedir. Mimarlık eğitim sürecinde teorik bilgi ile beraber uygulamayı içerecek bilgilerin edinimi öğrencilerin mesleki gelişmesinde değerlidir. Bu çerçevede, mimarlık öğrenimi sürecinde yapı, yapım sistemi, yapı bileşenleri, yapı elemanları vb. uygulamaya yönelik temel bilgilerin öğretildiği yapı bilgisi derslerinde verilen bilgiler önem kazanmaktadır. Bu çalışmada, yapı bilgisi dersi kapsamında yaptırılan maket çalışması ve uygulanan anket çalışması özelinde konu derinlemesine irdelenmektedir.

\section{Yöntem}

Çalışma, dört aşamada gerçekleştirilmiş olup ilk iki aşamayı çalışmaya yönelik hazırlık ve altyapı oluşturma, üçüncü aşamayı maket yapılması, son aşamayı ise anket uygulaması oluşturmaktadır. Çalışmanın hazırlık aşamasında öğrencilere ders ile ilgili genel bilgiler verilmiş ve ders konularının daha iyi anlaşılması amacıyla birey veya gruplar halinde maket yapacakları bildirilmiştir. Yapılması beklenen maketlerin yapım süreçleri ile ilgili örnek fotoğraflar ve videolar izletilerek çalışma hakkında ön bilgi edinmeleri sağlanmıştır. Ders kapsamında, yapı ve yap1 ile ilgili genel kavramlar, yapım sistemleri, yap1 elemanları, temeller, taşıyıcı sistemler, duvarlar, döşemeler, yalıtımlar ve bacalar konuları anlatılmıştır. Altyapı oluşturma aşamasında, derste anlatılan tüm bu içeriğin maket çalışmasına referans verilerek düşünülmesi gerektiği vurgulanmıştır. Ders konuları anlatılırken, öğrencilere deneyim kazandıracak bilgiler de verilmiştir. Örneğin, maket çalışmasında beton imalatı sırasında betonun çatlaması ihtimaline karşın gerekli tedbirlerin alınmasına yönelik öğrencilere fikir verilmiştir. Bu sayede, öğrencilerin yapı malzemelerinin yapım aşamasında davranışını anlamaları sağlanmaya çalışılmıştır. Maket çalışmaları grupları, 1 kişilik bir grup haricinde (17. Grup), en az 3 ve en fazla 6 kişilik olmak üzere toplamda 89 öğrenci ve 20 gruptan oluşmaktadır. Grupların belirlenmesinin ardından, öğrencilere ders kapsamında sunulan konuların tamamını kapsayan bir maket uygulaması yaptırılmıştır. Bu doğrultuda, uygulanan maket çalışmaları dört aşama ile gerçekleştirilmiştir. Bunlar; (1) Gruplarca tercih edilen temel çeşitleri uygulanacaktır, (2) Düşey taşıyıcı elemanlar (kolonlar) yapılacaktır, (3) Gruplarca tercih edilen döşeme çeşitleri uygulanacaktır, (4) Döşeme ve duvar kaplaması katmanları gösterilecektir şeklindedir. Sonuç ürünler, işlenen konuların makete nasıl ve ne kadarının işlendiği göz önüne alınarak derse giren öğretim elemanları tarafından karşılaştırmalı olarak değerlendirilmiştir. Değerlendirmede yapılan eleştiriler, öğrencilere bildirilmemiştir, ancak model çalışmaları beklenenden daha iyi sonuçlanmıştır. Ortaya çıkan ürünler, 17 Şubat - 16 Mart 2020 tarihleri arasında Fakülte Sergi Alanı'nda sergilenerek diğer öğrencilerin maketleri görmesi sağlanmıştır. Bununla birlikte, çalışma sonucunda 89 öğrenciden 53 öğrenci katılımı ile bir anket çalışması gerçekleştirilmiştir. Ankette altı seçmeli ve bir yorum sorusu bulunmakta olup yer alan tüm seçmeli soruların beş farklı kriterde değerlendirilmesi istenmiştir ( $1=$ Kesinlikle hayır, 2 = Hayır, 3: Kısmen, 4: Evet, 5: Kesinlikle evet). Seçilen kriterler; (1) Dersin haftalık ders saatlerinin artırılmasında fayda var, (2) Yapı ile ilgili ders sayısı artırılmalıdır, (3) Maket çalışması ile dönem boyunca yapılan uygulamaları daha iyi anladım, (4) Maket çalışması ile yap1 malzemeleri ile ilgili bilgilerimi artırdım, (5) Sonuç ürün öğretim elemanı tarafından değerlendirilmelidir, (6) Ders kapsamında maket uygulaması mimari tasarım derslerinde 
faydalı olmaya başlamıştır, ( 7) Ortaya çıkan ürünün (model) özeleştirisini yapınız şeklindedir. Anket sonuçlarıyla dersin işleyişi ile ilgili bazı öneriler geliştirilmiştir.

\section{Amaç}

Mimarlık öğrencileri, proje derslerinde tasarladıkları yapıların uygulanabilirliği konusunda bir takım bilgi eksiklikleri yaşamaktadırlar. Bu eksiklikler konusunda, eğitim süresince yapı ile ilgili destek dersleri verilmekte, verilen bilgilerin pekiştirilmesi doğrultusunda maket yapımı öğrenmenin önemli bir tamamlayıcısı haline gelmektedir. Bu araştırmada, mimarlık öğrencilerinin üç boyutlu görsel algılarını artıracak ve edinim biçimlerini geliştirecek maket yapımının mesleki öğrenimde etkililiği ölçülmeye çalışılmaktadır. Araştırmanın kapsamını Ondokuz Mayıs Üniversitesi, Mimarlık Fakültesi, Mimarlık Bölümü, 2019-2020 Eğitim Öğretim Y1lı Güz Dönemi’nde verilen "Yapı Bilgisi I" dersinde yapılan maket çalışmaları ve dersin sonunda öğrenciler ile yapılan anket uygulaması oluşturmaktadır. Maket çalışması ile öğrencilerin ileriye yönelik hem tasarım, hem de uygulama aşamasında kullanabilecekleri bilgilerle donatılmaları hedeflenmektedir.

\section{Bulgular}

Dersi alan öğrencilerin büyük bir çoğunluğu "dersin haftalık saatinin artmasının faydalı olacağını düşünüyorum" ölçütüne "hayır" ve "kesinlikle hayır" cevabını vermiş olup öğrencilerin düşüncelerinin ders saatinin artırılmasının faydalı olmadığı yönünde olduğu söylenebilir. Öğrencilerin üçte biri "yapı ile ilgili derslerin sayısının artması gerektiğini düşünüyorum" ölçütüne "kısmen" cevabını vermiştir. Buna karşıı dörtte bir oran "hayır" ve "kesinlikle hayır" cevabını vermiştir. Soruya "evet" ve "kesinlikle evet" cevabını veren öğrenciler yarıya yakındır. Bu iki ölçüte yönelik sonuçlar birlikte değerlendirildiğinde, öğrencilerin dersin haftalık saatinin artması yerine yapı ile ilgili derslerin farklılaşması ve bu derslerin artması yönünde fikir beyan ettikleri görülmektedir. Öğrencilere göre ders özelinde haftalık ders saati yeterlidir, yapı ile ilgili başka bilgileri içeren dersler ise yetersizdir ve artması gerekmektedir. Dersi alan öğrencilerin büyük bir çoğunluğu "maket ödeviyle dönem içinde yapılan uygulamaları daha iyi kavradım" ölçütüne "evet" ve "kesinlikle evet" cevabını, düşük bir oranı ise "hayır" ve "kesinlikle hayır" cevabını vermiştir. Bu sonuçlara göre, öğrencilerin çoğunluğu maket yapımı ödevinin öğrenim sürecinde konuları kavramakta yardımcı olduğunu ve bu sayede konuların daha iyi kavrandığını düşünmektedir. Büyük bir çoğunluk "maket ödeviyle yapı malzemeleri hakkında bilgim artmışırı" ölçütüne "evet" ve "kesinlikle evet" cevabını vermiştir. Buna karşın düşük bir oranı ise "hayır" ve "kesinlikle hayır" cevabını vermiş, beşte bir oranında ise "kısmen" cevabını vermeyi tercih etmiştir. Bu sonuçlara göre, öğrencilerin maket yaparken yap1 malzemeleri hakkındaki bilgilerinin arttı̆g belirtilebilir. Bilgisinin artmadığını düşünen küçük bir oranda öğrencilerin varlığı, bölümde yapı malzemeleri konusunda bir dersin olmamasından kaynaklanmaktadır. Öğrencilerin yapı ile ilgili başka derslerin olması gerektiğine vurgu yaptıkları değerlendirildiğinde, bu konuda bilinçli oldukları göze çarpmaktadır. "Sonuç ürünün (maketin) derste sunularak dersi veren öğretim üyesi tarafindan değerlendirilmesinin (sözlü) faydalı olacağını düşünüyorum" ölçütüne dersi alan öğrencilerin yaklaşık yarısı "kesinlikle evet" ve "evet" cevabını vermiştir. Yaklaşı dörtte biri "kısmen", düşük bir oranı ise "hayır" ve "kesinlikle hayır" cevabını vermiştir. Bu sonuçlara göre öğrenciler, maketlerin dersi veren öğretim üyesince sözlü değerlendirilmesinin eğitim sürecine katkı sağlayacağı görüşündedir. "Ders kapsamındaki maket uygulaması, mimari tasarım dersinde yararlı olmaya başlamışıı" ölçütüne yönelik değerlendirmelerde, öğrencilerin yarıya yakını "kısmen" olarak tercih belirtmiş, üçte bir oranında öğrenci "evet" ve "kesinlikle evet" cevabı vermiştir. Buna göre, öğrencilerin bu çalışmanın mimari tasarım dersine katkısı olduğunu düşündüğü belirtilebilir. Öğrencilerin 
yarıya yakınının kısmen cevabını vermesinde, çalışmanın zaman açısından kısa bir sürede bitmesi, maket çalışmasından elde edilen bilgilerin ve deneyimlerin proje süreçlerine taşınacak kadar uzun olmaması bulunmaktadır. "Yaptığınız makette sonuç ürünün (maketin) öz eleştirisini yapınız" ölçütü yoruma dayandığı için yapılan değerlendirmeler, öğrencilerin verdiği cevaplar doğrultusunda gruplandırılmıştır. Buna göre, dersi alan öğrencilerin önemli bir oranı değerlendirmelerinde maket uygulamasının faydalı olduğunu, maket yapımında süre konusunda planlama hatası yaptıklarını ve bu sebeple zorlandıklarını, ucuz malzeme kullanmanın sonuç ürüne kötü yansıdığını ve maketlerinin sağlam olmadığını, bu sebeple sonuç ürünü kaliteli bulmadıklarını belirtmişlerdir. Öğrencilerin bir kısmı diğer derslerine vakit ayırabilmeleri için maket çalışmasının ders saatleri içerisinde yapılmasını önermiştir. Sadece 1 öğrenci ders kapsamında maket yaptırılmaması gerektiğini ifade etmiştir. Özetle, anket sonuçları ile katılımcı öğrencilerin yapı ile ilgili derslerin sayısı, niteliği ve içeriği konusundaki değerlendirmeleri ortaya konulmuştur. Bu sayede, ders işleyiş süreci ve yapılabilecek değişiklikler konusunda öneriler geliştirilmiştir.

\section{Tartıșma ve Sonuç}

Mimarlık eğitimi sürecinde verilen yapı derslerinin amaçlarından biri, mimar adaylarının yapım aşamasını gerçeğe yakın bir şekilde kavrayabilmesi ve uygulama detaylarındaki eksikliklerin farkına varmalarıyla buna yönelik çözüm üretmelerini sağlamaktır. Bunu sağlamanın en iyi yollarından biri hiç şüphesiz ders kapsamında maket uygulamalarının yaptırılmasıdır. Bu çalışma kapsamını oluşturan maket uygulamaları ile ders kapsamında işlenen yapı ile ilgili temel bilgilerinin kolayca kavranması sağlanabilmektedir. Ayrıca, mimarlık öğrencilerinin maket yapımına ve dersin işleyişine yönelik hazırlanan anket sorularına verdiği cevaplar, maket çalışması ile derste işlenen konuların daha iyi kavrandığını, yapı malzemeleri konusunda bilgi düzeylerinin arttığını, çalışmanın proje derslerinde yararlı olduğunu ortaya koymuştur. Çalışma ile, mimarlık eğitiminde proje atölyelerine destek olarak işlenen yapı bilgisi derslerinde maket uygulamalarının gerçekleştirilmesinin öğrencilere büyük bir katkı ve mesleki açıdan avantaj sağlayacağı ortaya koyulmaktadır.

\section{Öneriler}

Ders içerisinde öğrenilen bilginin, belirli ölçeklerde çizim uygulamaları ve daha sonra maket yapımı olarak "öğren-çiz-maketini yap" şeklinde geliştirilen bir yöntem ile öğrencilerin her hafta konu ile ilgili maket bölümlerini ders saati içerisinde yapması sağlanmalıdır. Maket yapma süreci böylelikle dönem içerisinde daha sağlıklı ilerleyecektir. Ayrıca, maket aşamalarının dönem sonunda jüri şeklinde tartışma ortamında yorumlanması ve değerlendirilmesi sağlanmalıdır. Böylelikle, yapı sistemleri hakkında öğrencilerde daha etkin bir öğrenme gerçekleşecektir. Sonuç itibariyle, yukarıda detaylarıyla izah edilen maket ile öğrenim yönteminin, öğrencilerin yapı konusunda daha fazla bilgi edinmeleri ve mevcut bilgilerini pekiştirmeleri açısından etkin ve verimli bir yöntem olduğu görülmektedir.

\section{Araștırmanın Sınırlılıkları ve Gelecek Araștırmalar}

Bu araştırma, Ondokuz Mayıs Üniversitesi Mimarlık Bölümü, 2019-2020 Akademik Yılı Güz Dönemi içerisinde verilen Yapı Bilgisi I dersiyle sınırlı olup bir eğitim öğretim dönemi içerisinde yürütülen çalışmanın sonucunu göstermektedir. Bu sebeple, araştırmanın kapsamı farklı zamanlarda ve diğer üniversitelerde konu ile ilgili yapılacak diğer çalışmalarla genişletilebilir. $\mathrm{Bu}$ doğrultuda, statik bir durumu ifade eden bu çalışma, konuyla ilgili yapılacak çalışmaların dinamik bir eğitim sürecinde değerlendirilmesini sağlayacaktır. Buna göre, diğer üniversitelerde yapılacak çalışmalarla karşılaştırma yapılabilecek, özgün ve değerli sonuçlar ortaya koyulacaktır. 


\section{Yazar Katkıları}

"Giriş, A.B .; Türkiye'de mimarlık eğitiminde yapı ile ilgili dersler, A.B .; yöntem, A.B., N.S.K. ve Y.G .; bulgular, A.B., N.S.K. ve Y.G .; tartı̧̧ma ve sonuç, A.B., N.S.K .; öneriler, A.B., N.S.K. ve Y.G .; referanslar, A.B., N.S.K .; yazma, inceleme ve düzenleme, A.B.”

\section{Yayın Etiği}

Araştırma ve Yayın Etiği'ne uyuldu

\section{Teșekkür}

Yazarlar, sergi afişi tasarımındaki yardımlarından dolayı grafik tasarım uzmanı Dr. Öğretim Üyesi Serpil Kaptan'a teşekkür eder. 